\title{
SWOT Analysis of Rural Bank and Marketing Strategy
}

\author{
Wei Deng \\ Business College, University of Science and Technology of Wuchang , Wuhan, 430223, China
}

Keywords: Rural bank, SWOT analysis, Marketing strategy

\begin{abstract}
Rural bank is an important force of supporting rural economic development. The development of rural banks can help construct healthier and more diversified rural financial system, effectively improve overall financial environment of rural development and solve financial repression problem existing in Chinese rural development. This paper discusses the development of rural bank and problems from four aspects (Superiority, Weakness, Opportunity and Threat) and proposes marketing strategies for rural banks.
\end{abstract}

\section{Introduction}

In recent rural economic development, the rural bank becomes an emerging force which promotes rural economic development. To continuously promote development of rural economy, CBRC issued Several opinions on adjusting and access policy of relaxing banking financial institutions in rural areas and better supporting construction of socialism new countryside in 2006. The document aims to stress guidance of various kinds of funds and capital so as to provide financial services for rural households and promote sound development of rural economy.

\section{SWOT analysis of rural bank development strategy}

To continuously facilitate orderly development of rural economy and solve financing difficulty of rural areas in development process, China started to issue related policies and regulations from 2006 and allowed rural areas to set up new rural financial institutions, including rural bank, finance corporation and rural loan society ${ }^{[1]}$. As of March 2007, Sichuan Province set up Yilong Huimin Village Bank. This marks China's new rural financial institution is born officially. With continuous development of rural economy and development demand, the rural bank has become an important force for rural areas to develop new economy. To scientifically and rationally apply rural financial institutions to promote continuous perfection of rural financial environment, SWOT analysis is used to analyze rural banks.

\section{Strength analysis of rural bank in rural economic development}

Firstly, because the rural bank has certain geographical relationship and interpersonal relationship with borrowers, information cost is one of the strengths. Hence, the phenomena where the borrowers break the contract may be easily avoided. The borrower's moral level is guaranteed. Once the borrower break the contract, large cost will be paid. Generally, in the operation process of rural bank, among the shareholders of rural bank, there should be at least one financial institution with the license which can serve as one of initiators of the rural bank. This can effectively make sure this bank can basically operate the business within the allowed scope according to the operation mode of commercial bank so as to effectively avoid violation and financial risks ${ }^{[2]}$. Rural banks can properly adjust deposit interest rate and loan interest rate with the allowed scope of operation and simplify the operating mechanism in view of cognition level of local rural masses so that peasant households, rural medium and small enterprises can seize market opportunity and boost economic benefit. This has greater strength than rural credit cooperatives and some large and medium urban commercial banks. Sine rural credit cooperatives and some large and medium urban commercial banks need to submit the application, check and approve the application, peasants may miss the business opprotuntyy. Meanwhile, because rural banks can go deep into rural market, accurately master how to 
provide proper individual services for customers and subtly urge small and medium financial institutions to explore market segmentation and supply of differential and individual services. This will effectively facilitate innovation of products and services in the financial market and then continuously boost competitiveness of each rural financial institution.

Secondly, since the rural bank is registered at CBRC and directly supervised by CBRC, its business activity and service are allowed by Central Bank. Besides, the setup foundation of rural bank is that shareholding ratio of single banking financial institution within the territory of China is higher than $20 \%$, but the total shareholding ratio of single natural person, single other non-bank business entity and its related party cannot exceed $10 \%$. The rural bank is not restricted by local government in its operation and management process. Local politics and banking operation are separated, which can effectively avoid local government monopoly in rural financial development process. In its operation and management process, the rural bank fully applies modern advanced operation and management concepts and means, and closely combines local economic development, the masses needs and features of the rural bank to construct perfect rural financial institution ${ }^{[3]}$.

\section{Weakness analysis of rural bank in rural economic development}

\section{Operating management performance of rural banks has many problems}

Because rural banks are established on the basis of new rural economy, they are generally set up in the areas where economic development lags behind. High-tech industry and leading enterprises in these areas are few, economic income generally depends on traditional agricultural economy. Besides, as agricultural development weakens, local economic development level is not high. The competitiveness of rural banks is far from enough, compared with local large and medium commercial banks. Thus, they have small performance and profit space. In addition, customers of rural banks are mostly peasants. Peasants need to large sum of loans when they develop traditional planting industry and breeding industry, so the profit rate is low and agricultural products have certain risks.

\section{Human resources of rural banks in operating management also have many problems}

In Chinese rural areas and especially in western rural areas, there is short of financial talents. If banks' salary is not high, it is very difficult to recruit professional talents who comply with the demand of banking business development. Rural banks are faced with such an arduous task in operation and development process: on the one hand, they should try to compress operation management cost; on the other hand, they should recruit professional talents to carry out professional operation management. Thus, the number of peasant users is large, while professional credit employees are insufficient in the operation process of rural banks. Such situation leads to a big problem for peasants' post-credit service management. It is very hard to control credit risks and operating risks.

\section{Development opportunity analysis of rural banks in rural economic development}

As per Rural financial service distribution atlas of China banking ${ }^{[4]}$ updated by CBRC in 2007, although positive and clear performance has appeared in financial services in rural economic development process, it is still necessary to further boost development of rural financial economy and especially enhance development of rural bank work in order to achieve rational allocation and development of Chinese financial service financial resources. The following aspects are mainly involved. Firstly, there are a large number of peasant loan providers and concentrate. Nearly 98.7\% peasants in China can gain loans from rural cooperative financial institutions and agricultural banks. Secondly, per-capita loan level between rural area and urban area still has a large gap, so the development space is large. Thirdly, in expanded rural space, branches of rural banks and other financial institutions are distributed sparsely, and even some villages and towns have no financial institution. The competition of rural bank development is not sufficient enough. Finally, regional 
allocation of China's financial resources is not balanced. In China's east-central-west regions, inter-regional and intra-regional economic development level and financial service have different degrees of differences. Meanwhile, compared with general commercial banks, the requirements of registered capital and capital scale are relatively loose when rural banks are set up. Thus, rural banks have large development space and possibility in future operation development. It is a rare and commendable development opportunity.

\section{Threat analysis of rural bank in rural economic development}

Firstly, rural banks have policy threat in rural economic development. There is no specific definition of deposit reserve rate for rural banks. Rural banks as financial institutions of rural economic development and transformation cannot specify whether the deposit reserve rate implements deposit reserve rate of general commercial banks or deposit reserve rate of rural credit cooperatives. They cannot clearly define the execution policy of deposit reserve rate. Besides, there is corresponding deposit reserve rate formulated in allusion to this phenomenon. Rural banks need to further specify and perfect it in future development. Meanwhile, rural banks have no established loan and deposit interest rate flotation intervals, because rural banks are emerging financial institutions in rural economic development. Although People's Bank of China allows financial institutions to properly adjust loan and deposit interest rate flotation intervals, there is still no explicit provision about loan and deposit interest rate flotation intervals of rural banks ${ }^{[5]}$. Moreover, since China has not established perfect deposit insurance system, China's banking economy has certain risks in loan and deposit business. If payment crisis appears in villages and towns, grass-roots Central Bank fails to formulate specific countermeasures and policies. To reduce risks of rural banks in the development process, it is required to formulate and issue corresponding policies according to development and features of rural banks as soon as possible.

Secondly, services of rural banks also have certain threat. Because settlement business of rural banks are directly connected with local People's Bank of China, if rural banks carry out settlement through enterprises' agent bank and cannot bring this business in payment settlement system of People's Bank of China, certain obstruction will be caused for People's Bank of China to monitor capital flow. Besides, capital flow risks of rural banks will increase.

Finally, since the scale of rural banks is small, settlement and account management is not sound. They cannot actively apply advanced computer technology. Thus, anti-money laundering monitoring mechanism is not perfect. Certain defects still exist in examination and approval of large amount of cash, block trade report and suspicious trade report business handling. Thus, anti-money laundering monitoring is not done well. It is necessary to perfect and standardize it in future work.

\section{Marketing strategy of rural banks}

Firstly, rural banks should specify their basic functions of serving rural economic development. Employees should establish good service awareness and provide superior services for customers. This is also the main mode and means for each bank to gain development in development competitions of financial institutions. Quality-service-marketing triune management idea should be established for rural banks. In work, employees should regard customers as the center, provide differential and individual services for peasants according to peasants' needs in rural economic development, try to meet their needs and offer "one-stop” services for them. Furthermore, relevant feedback system should be established to make peasants feed back problems exiting in operation process of rural banks in time, correct and perfect them in time.

Secondly, service quality management in operation process of rural banks should be enhanced continuously. Seeing from current development situation of China's rural banks, although most banks have been able to realize the importance of serving peasants, systematical and perfect service quality management is still not established. Thus, service behaviors of bank employees are not standardized, and there is no uniform standard. Thus, service quality is uneven. To enhance market development competitiveness of rural banks, it is required to actively refer to advanced experience of bank 
management, combine actual conditions of local rural economic development and achieve modern rural bank management so as to improve service quality. Besides, thorough remedy mechanism should be established. For the problems existing in operation process, it is required to correct them and reduce the loss of peasants and banks.

Finally, rural banks should reorganize and optimize allocation of internal businesses as ell as form management and development brand. The business of rural banks alters with rural economic development. Hence, banks should reorganize internal business according to actual conditions. They may design bank business process with the help of electronic information technology or set some practical value added services as per customer value daffiness. Rural banks should establish their own financial service brand in accordance with economic development features and service features of rural banks. Rural banks also needs to carry out technological innovation and service innovation continuously, improve and upgrade financial service brand, actively develop potential market and effectively attract potential customers.

\section{Conclusions}

In one word, rural banks construct sound and favorable financial system in rural economic development process can effectively solve financing difficulties and multiple problems and promote transformation and development of rural economy. Based on SWOT analysis, this paper specifies the strength, weakness, opportunity and threat of rural banks in the development process. In future operation process, rural banks may formulate targeted operation strategy to promote continuous development of rural banks. Relevant leaders and initiators of rural banks should know the problems and defects of rural banks in the development process and solve them in time so as to boost of rural banks of rural banks.

\section{References}

[1] Ding Tao, Study on SWOT analysis of new rural financial institution and sustainable strategy. Financial Theory \& Practice, 2011(6)

[2] Wang Wei, Liu Yan, Wang Sujuan, SWOT-based study on sustainable development of rural banks in Henan. Financial Theory \& Practice, 2014(9)

[3] Han Zhihua, Ma Lixia, Lu Guohua, SWOT analysis of rural banks in Hebei and sustainable development strategy. Heilongjiang Journal of Animal Science and Veterinary Medicine, 2014(7)

[4] Hou Dexin, Pang Haifeng, Zhang Li, sustainable development strategy of Chinese rural banks based on SWOT analysis - case study of Minsheng Rural Bank. Modern Business, 2013(10)

[5] Research group of Hua Xia Bank Chengdu Branch, Wang Bolin, Luo Ranran, business pattern and development path of rural banks - investigation and survey of some rural banks in Sichuan. Southwest Finance, 2015(11) 